Marceli Burdelski

\title{
Dr Mahatir bin Mohamad - nota biograficzna
}

Premier Malezji dr Mahatir Mohamad należy do wybijających się polityków Azji w okresie powojennym. Urodził się 20 grudnia 1925 roku w Alor Setar, w stanie Kedah. Ukończył Wydział Lekarski Uniwersytetu Malajskiego w Singapurze. W latach 1954-1957 pracował jako lekarz w państwowej służbie zdrowia, a następnie prowadził praktykę lekarską swoim rodzinnym mieście. W czasie studiów poznał swą przyszłą żonę, dr. Siti Hasinah Mohod Ali.

Działalność polityczną rozpoczął w 1945 roku, wstępując do Związku Malajskiego i Malajskiego Ruchu Młodzieżowego w Kadahu. Po raz pierwszy członkiem parlamentu został w 1964 roku, jednak w kolejnych wyborach do parlamentu nie zastal wybrany. Jego członkiem zostaje ponownie dopiero $\mathrm{w}$ roku 1973 i jest nim do dziś.

Członkiem partii UNMO jest od momentu jej utworzenia w 1946 roku. W latach 1965-1969 wchodził w skład Rady Naczelnej. W 1969 r. zostaje usunięty z szeregów partii UNMO za napisanie listu krytykującego ówczesnego premiera Tunku Abdul Rahmana. Przed ponownym powrotem do UNMO pisze słynną i kontrowersyjną książkę The Matczy Dilemma, w której wyjaśnia przyczyny zacofania ekonomicznego Malajów. Uznaje, że rozwój kraju powinien opierać się na interwencjonizmie państwowym. Książka ta została zabroniona w Malezji.

W 1975 r. zostaje jednym z trzech wiceprzewodniczacych partii, w roku 1978 pierwszym wiceprzewodniczącym, a od 1981 roku przewodniczącym. Mahatir zajmował szereg stanowisk w administracji rządowej. Był ministrem oświaty, handlu, przemysłu i wicepremierem. W lipcu 1981 roku został czwartym premierem w historii Malezji i stanowisko to piastuje do dziś.

Żonaty, ma czterech synów i trzy córki.

Jest autorem czterech książek: The Matay Dilemma, The Challenge, The Way Forward, New Real for Asia. 